\title{
ISOLATION AND DETERMINATION OF CHEMICAL COMPOUNDS FROM N-HEXANE FRACTION OF THE SINTOK STEM BARK (Cinnamomum sintoc Bl.)
}

\author{
Y. Iskandar ${ }^{1}$ and R. Mustarichie ${ }^{2, *}$ \\ ${ }^{1}$ Department of Biology Pharmacy, Faculty of Pharmacy, \\ Universitas Padjadjaran, Indonesia 45363 \\ ${ }^{2}$ Department of Pharmaceutical Analysis and Medicinal Chemistry, Faculty of Pharmacy, \\ Universitas Padjadjaran, Indonesia 45363 \\ * E-mail: resmi.mustarichie@unpad.ac.id
}

\begin{abstract}
It was reported that all fractions of Cinnamomum sintoc methanol extract had antioxidant properties which could delay, slowed down and prevented the occurrence of oxidation reactions caused by free radicals that could trigger degenerative diseases such as cancer, diabetes, and liver. This study aims to isolate and determine chemical compounds from n-hexane fraction of Sintok (C.sintoc B1.) stem bark. The material was macerated using ethanol $70 \%$ followed by fractionation using n-hexane and water solvent. Phytochemical screening was performed to the hexane fraction. Vacuum liquid chromatography (VLC) was used to separate and isolate compounds using and preparative thin layer chromatography. The obtained isolates called $\mathrm{FH}_{3-2}$ and $\mathrm{FH}_{3-3}$ and determined using UV and IR spectrophotometers and Gas Chromatography-Mass Spectrometry. The ultraviolet spectrum of $\mathrm{FH}_{3-2}$ isolate showed the maximum wavelengths of 208, 229, and $275 \mathrm{~nm}$. The infrared spectrum showed the presence of O-H, C-H aromatic groups, $\mathrm{C}=\mathrm{C}$, and $\mathrm{C}-\mathrm{O}$. The mass spectrum gave $\mathrm{m} / \mathrm{z}$ : $164[\mathrm{M}+], 149,131,121,103,91,77,55,51$ having 97\% similarity with eugenol. The ultraviolet spectrum of $\mathrm{FH}_{3-3}$ isolate showed a maximum wavelength of $206 \mathrm{~nm}$. The infrared spectrum showed the presence of $\mathrm{O}-\mathrm{H}, \mathrm{C}=\mathrm{C}$, and $\mathrm{C}-\mathrm{O}$ groups. The mass spectrum gave $\mathrm{m} / \mathrm{z}: 222$ [M+], 208, $189,161,147,135,121,105,93,81,67,43$ having $85 \%$ equality with juniper camphor. It could be concluded there were two dominant compounds of the fraction of n-hexane of the Sintoc stem bark i.e eugenol and juniper camphor. Keywords: Cinnamomum sintoc, Sintok, Eugenol, Juniper Camphor, GC-MS.
\end{abstract}

(C) RASĀYAN. All rights reserved

\section{INTRODUCTION}

Sintok plants (Cinnamomum sintoc B1.) include the Lauraceae family, grown in West and Central Java, Malaysia and Thailand. The sintok (Indonesian) bark has a smooth texture, rather mild, soft, somewhat dense, grayish-brown red color, aromatic smell. The bark is empirically used by the public for the treatment of intestinal worms, murine drugs with seizures, wounds and swelling due to animal bites, dysentery, thrush, and fragrance ${ }^{1-5}$. Based on research conducted by BPOM, a bark of sintok contains phenylpropanoid or alkenyl benzene compounds ${ }^{6}$. In addition, Phutdhawong stated that the main content of the essential oil of sintok leaf is linalool $(36.90 \%)$ and cadinol $(7.03 \%)^{7}$. In a study conducted by Sunardi et.al reported that the main content of the synthetic bark is eugenol and safrol ${ }^{8}$. Groups of compounds such as eugenol and safrol have been found to have an analgesic and anti-inflammatory effect ${ }^{9}$. In 2014, Alfira in her thesis stated that all fractions (water, ethyl acetate, and hexane fractions) have antioxidant activity by using DPPH (1,1-diphenyl, 2- picrylhydrazyl $)^{10}$. It is reported that all fractions of C.sintoc methanol extract have antioxidant properties. It is understood that antioxidant compounds can delay, slow down and prevent the occurrence of oxidation reactions caused by free radicals that can trigger degenerative diseases such as cancer, heart, arthritis, diabetes, and liver. These antioxidant properties will be known if we know the compounds contained in the plants under study9.

The aim of this study was to report the compounds contained in the $C$. sintoc n-hexane fraction along with the isolation method and the appropriate determination to obtain the compound. Another faction analysis

Rasayan J. Chem., 12(2), 898-906(2019)

http://dx.doi.org/10.31788/RJC.2019.1225188

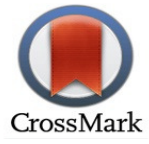


will be presented in our other reports. The compounds obtained can then be verified whether they are antioxidants as anti-cancer by using the in-silico or in-vitro using cell-line methods ${ }^{11-15}$.

\section{Material and Methods}

\section{EXPERIMENTAL}

\section{Sample Collection}

Dried sample of sintok was purchased from the Manoko Experimental Garden, Lembang, West Java, verified at the Laboratory of Taxonomy, Biology Department, Faculty of Mathematical and Physical Sciences, Universitas Padjadjaran

\section{Extraction and Fractionation}

Sintok powder was extracted using macerator equipment with $70 \%$ ethanol as a solvent based on Mustarichie et.al method ${ }^{16,17}$. The resulting filtrate was concentrated by rotary vacuum evaporator (Rotavapor, Buchi RII) and then evaporated on a water bath at $50^{\circ} \mathrm{C}$ till constant weight to obtain the viscous ethanol extract. The extract was fractionated using liquid-liquid extraction with n-hexane and water solvent following modification of Mustarichie et.al method ${ }^{17}$.

\section{Phytochemical Screening}

Phytochemical screening of extracts and fractions using modifications of the Farnsworth method ${ }^{18}$. Actually, the phytochemical test was a procedure carried out by many researchers in evaluating plants that were thought to have medicinal effects ${ }^{19,20}$.

\section{Fractionation and Determination of Extracts}

Vacuum Liquid Chromatography (VLC): VLC was used to separate and isolate desired fractions. The nhexane fractional was introduced into the VLC column and eluted with methanol: chloroform mixture with multilevel polarization. Each subfraction was tested by TLC with a suitable developer to obtain a spot. The TLC used a stationary phase of silica gel GF254 and its mobile phase of chloroform: methanol with a variation. The VLC method was guided by Indonesian Herbal Pharmacopoeia ${ }^{21}$.

\section{Purification and Purity Isolate Test}

Purification was done by recrystallization using methanol. The crystals contained in the vials were dissolved with methanol and the exterior of the vial was soaked in warm water with a temperature range below $40^{\circ} \mathrm{C}$ while rocking slowly. Then, directly inserted into cold water, not to be submerged or water went into the vial. The isolate purity was tested by using two-way TLC. The stationary phase was used in the form of silica gel 60 with two different mobile phase systems.

\section{Detection Method}

The resulting isolates were then identified and determined by ultraviolet-visible spectrometry UV-Vis (Shimadzu UV 1800U), Spectroscopy FT-IR spectrometry (Shimadzu 8400), and GC-MS (Shimadzu QP 2010SE).

\section{Plant Determination}

\section{RESULTS AND DISCUSSION}

The result of plant determination indicated that simplicia was stem bark of sintok (Cinnamomum sintoc B1.).

\section{Results of Plant Materials Processing and Microscopic Analysis}

Microscopic characteristics of the sintok stem bark powder were indicated by the presence of stone cells, oxalic crystals, oil cells, sclerenchyme fibers, and sclereids.

\section{Extraction}

The results of simplicia extraction of the bark of sintok produced a thick brown condensed extract of $9.03 \%$ of the weight of the dried sample.

\section{Fractionation}

The result of fractionation obtained by $n$-hexane fraction resulted in $10.48 \%$ and water fraction yield of $89.51 \%$. The n-hexane fraction was thick yellowish brown oil with brown-green precipitate with an aromatic distinctive odor. Water fraction in the form of thick red-brown extract. 


\section{Phytochemical Screening}

Phytochemical screening was performed on extracts and fractions. The results of phytochemical screening of the extract, n-hexane and wáter fractions of sintok bark can be seen in Table-1.

Table-1: Phytochemical Screening of Extract, n-Hexane and Water Fractions of C. sintoc

\begin{tabular}{c|c|c|c}
\hline Compounds & Ethanol Extract & n-Hexane Fraction & Water Fraction \\
\hline Alkaloids & - & - & - \\
\hline Flavonoids & - & - & - \\
\hline Tannin & + & + & + \\
\hline Polyphenols & + & + & + \\
\hline $\begin{array}{c}\text { Monoterpenoid and } \\
\text { sesquiterpenoid }\end{array}$ & + & - & - \\
\hline Steroid & - & + & - \\
\hline Triterpenoid & + & - & + \\
\hline Quinone & + & - & - \\
\hline Saponins & - & + & + \\
\hline
\end{tabular}

Notes : (+) : Detected, (-) : Not detected

\section{Thin Layer Chromatography (TLC)}

The thin layer extract chromatography was performed using silica gel 60 F254 silicone phase, toluene: ethyl acetate (93: 7) developer and detected using $366 \mathrm{~nm}, 254 \mathrm{~nm}$ UV lights and vanillin-sulfuric acid. The results of TLC of sintok bark extract can be seen in Table-2.

Table-2: TLC of Ethanol Extract of C. Sintoc

\begin{tabular}{c|c|c|c|c}
\hline \multirow{2}{*}{$\begin{array}{c}\text { Spotting } \\
\text { to- }\end{array}$} & Rf & \multicolumn{2}{|c}{ UV Light } & \multirow{2}{*}{ Vanillin-Sulphuric Acid } \\
\cline { 3 - 4 } & & $254 \mathrm{~nm}$ & $366 \mathrm{~nm}$ & - \\
\hline 1 & 0.96 & purple & purple & purple \\
\hline 2 & 0.90 & purple & - & Yellow \\
\hline 3 & 0.79 & - & - & purple \\
\hline 4 & 0.65 & - & purple & red-brown \\
\hline 5 & 0.61 & purple & - & plue \\
\hline 6 & 0.51 & purple & light blue & blue \\
\hline 7 & 0.40 & purple & - & purple \\
\hline 8 & 0.31 & - & orange & purple \\
\hline 9 & 0.28 & - & orange & red \\
\hline 10 & 0.17 & purple & - & - \\
\hline 11 & 0.09 & - & - & \\
\hline 12 & 0.00 & & &
\end{tabular}

\section{TLC of n-Hexane Fraction}

Thin layer chromatography of the n-hexane fraction was carried out using silica gel 60 F254 silicone phase, the developer of n-hexane: ethyl acetate (9:1) and detected using $366 \mathrm{~nm} \mathrm{UV}, 254 \mathrm{~nm}$ UV lights and vanillin-sulfuric acid. 15 spots were shown on the TLC plate (see Table-3).

Table-3: Vacum Liquid Chromatography (VLC) Result of n-Hexane Fraction

\begin{tabular}{c|c|c|c}
\hline Fraction & Organoleptic & $\begin{array}{c}\text { Weight } \\
(\mathrm{mg})\end{array}$ & $\begin{array}{c}\text { Yields } \\
(\%)\end{array}$ \\
\hline $\mathrm{FH}_{1}$ & $\begin{array}{c}\text { creamy yellow-orange oil, distinctive } \\
\text { smell }\end{array}$ & 318.5 & 6.00 \\
\hline $\mathrm{FH}_{2}$ & yellowish oil, distinctive smell & 407.9 & 7.69 \\
\hline $\mathrm{FH}_{3}$ & thick orange oil, aromatic smell & 1625.3 & 30.66 \\
\hline $\mathrm{FH}_{4}$ & thick greenish oil, smelly & 479.6 & 9.04 \\
\hline $\mathrm{FH}_{5}$ & thick green brown oil & 309.0 & 5.83 \\
\hline $\mathrm{FH}_{6}$ & yellow brownish oil & 315.4 & 5.95 \\
\hline \multicolumn{2}{|c|}{900}
\end{tabular}




\section{Separation of the n-Hexane Fraction Component}

Separation of the n-hexane fraction component was performed using VLC resulting in 30 fractions. The fraction monitored the pattern of spotting through TLC to see the similarity of spotting patterns of each fraction. A fraction with the same spotting pattern was combined so that six major fractions of n-hexane $\left(\mathrm{FH}_{1}-\mathrm{FH}_{6}\right)$ were obtained.

\section{Purification of Compounds}

Purification of $\mathrm{FH}_{3}$ was done using preparative TLC. $\mathrm{FH}_{3}$ was further isolated because it had relatively more yields and had a strong aromatic distinctive odor similar to pepper and cloves. The results of preparative $\mathrm{TLC} \mathrm{FH}_{3}$ can be seen in Table-4.

Table 4: TLC Preparative of $\mathrm{FH}_{3}$

\begin{tabular}{c|c|c|c}
\hline Bands & Rf & UV $366 \mathrm{~nm}$ & Vanillin-Sulphuric Acid \\
\hline $\mathrm{FH}_{3-1}$ & 0.88 & Light blue & - \\
\hline $\mathrm{FH}_{3-2}$ & 0.60 & dark purple & red-brown \\
\hline $\mathrm{FH}_{3-3}$ & 0.42 & - & purple \\
\hline $\mathrm{FH}_{3-4}$ & 0.28 & Light blue & - \\
& 0.29 & - & blue \\
\hline
\end{tabular}

\section{Compounds Purity Test}

TLC 2-dimensional isolate $\mathrm{FH}_{3-2}$ produced single purple patches under $366 \mathrm{~nm}$ UV light and brown-red after sprayed with vanillin-sulphuric acid whereas isolate $\mathrm{FH}_{3-3}$ produced purple single spots sprayed with vanillin-sulphuric acid spray. This indicated that the isolates $\mathrm{FH}_{3-2}$ and $\mathrm{FH}_{3-3}$ had been relatively pure.

\section{Spectrophotometry Ultraviolet}

Isolates $\mathrm{FH}_{3-2}$ and $\mathrm{FH}_{3-3}$ were identified using ultraviolet spectrophotometry at 200-300 nm wavelength intervals in methanol solvent. Isolate $\mathrm{FH}_{3-2}$ showed the maximum wavelength ( $\lambda$ maks) 208, 229, and 275 $\mathrm{nm}$ whereas $\mathrm{FH}_{3-3}$ isolate showed $\lambda \max 206 \mathrm{~nm}$. The maximum wavelength at $208 \mathrm{~nm}$ was thought to arise from the electronic transition of the isolated double bond while the maximum wavelength at 229 and 275 $\mathrm{nm}$ was thought to arise from the electronic transition of the conjugated double bond ${ }^{22,23}$. The ultraviolet spectrum of $\mathrm{FH}_{3-3}$ isolate gave $\lambda$ maks at $206 \mathrm{~nm}$. From this wavelength, it was suspected that there was an electronic transition from an isolated double bond ${ }^{22}$.

\section{Infrared Spectrophotometry}

Isolates $\mathrm{FH}_{3-2}$ and $\mathrm{FH}_{3-3}$ were identified using infrared spectrophotometry at $4500-500 \mathrm{~cm}-1$ wavenumbers on potassium bromide discs. The results of infrared spectrophotometry identification of $\mathrm{FH}_{3-2}$ and $\mathrm{FH}_{3-3}$ isolates can be seen in Table-5 and 6 .

Table-5: IR Results of Isolate FH3-2

\begin{tabular}{c|c|c|c}
\hline $\begin{array}{c}\text { Wavenumbers } \\
\left(\mathrm{cm}^{-1}\right)\end{array}$ & Shape band & Intensity & Presumption \\
\hline 3450 & wide & medium & stretch O-H \\
\hline 3087 & sharp & weak & stretch C-H aromatic \\
\hline 3028 & sharp & weak & stretch C-H aromatic \\
\hline 2925 & sharp & strong & stretch C-H aliphatic symmetry \\
\hline 2857 & sharp & medium & stretch C-H aliphatic asymmetry \\
\hline 1740 & sharp & medium & stretch C=C \\
\hline 1594 & sharp & medium & stretch C=C aromatic \\
\hline 1454 & sharp & medium & stretch C-O aliphatic \\
\hline 1128 & sharp & medium &
\end{tabular}

Isolates were analyzed using infrared spectrophotometry to determine functional groups contained in isolated molecules. The infrared spectra of $\mathrm{FH}_{3-2}$ isolate showed an $\mathrm{O}-\mathrm{H}$ strain of $3450 \mathrm{~cm}^{-1}$. The absorption bands at 3087 and $3028 \mathrm{~cm}^{-1}$ with weak intensity were thought to arise from the aromatic C-H strain 
RASĀYAN J. Chem.

Vol. 12 | No. 2 |898 - 906| April - June | 2019

reinforced by the presence of an aromatic $\mathrm{C}=\mathrm{C}$ strain of $1594 \mathrm{~cm}^{-1}$. The absorption bands at 2925 and $2857 \mathrm{~cm}^{-1}$ were thought to be derived from the symmetric and asymmetric $\mathrm{C}-\mathrm{H} \mathrm{sp} 3$ stretches reinforced by the aliphatic C-H strain band of $1454 \mathrm{~cm}^{-1}$. The absorption band at $1740 \mathrm{~cm}^{-1}$ was thought to be derived from the $\mathrm{C}=\mathrm{C}$ strain. The medium-intensity absorption bands at $1128 \mathrm{~cm}^{-1}$ were thought to originate from the $\mathrm{C}-\mathrm{O}$ strain on tertiary alcohol ${ }^{24,25}$.

The infrared spectra of $\mathrm{FH}_{3-3}$ isolate showed an $\mathrm{O}-\mathrm{H}$ strain of $3434 \mathrm{~cm}^{-1}$. The absorption bands at 2937 and $2863 \mathrm{~cm}^{-1}$ were thought to originate from the symmetric and asymmetric $\mathrm{C}-\mathrm{H}$ sp3 strains reinforced by an aliphatic C-H strain of $1460 \mathrm{~cm}^{-1}$. The absorption band at $1711 \mathrm{~cm}^{-1}$ was thought to be derived from the C $=\mathrm{C}$ strain. The absorption bands at $1113 \mathrm{~cm}-1$ wave numbers were thought to originate from the $\mathrm{C}-\mathrm{O}$ strain on tertiary alcohols. The absorption bands at $1062 \mathrm{~cm}^{-1}$ were thought to originate from the $\mathrm{CH} 2$ strain in the terpenoid cyclic system ${ }^{23,30}$.

\section{GC-MS}

Based on the gas chromatographic analysis, isolates $\mathrm{FH}_{3-2}$ and $\mathrm{FH}_{3-3}$ hade retention time of 19,248 and 20,345 min respectively. From the mass spectrum, it was known that the $\mathrm{FH}_{3-2}$ isolate had a molecular weight of 164 with the molecular structure of $\mathrm{C}_{10} \mathrm{H}_{12} \mathrm{O}_{2}$. Isolate $\mathrm{FH}_{3-2}$ had a $\mathrm{m} / \mathrm{z}$ fragmentation pattern (relative intensity): 164 (100, base peak), 149 (37), 131 (32), 121 (19), 103 (39), 91 (36), 77 ( 51 ), 55 (46), 51 (30). The mass spectral pattern of $\mathrm{FH}_{3-2}$ was similar to the eugenol mass spectrum pattern with a $97 \%$ equity index. Based on the mass spectra, it was known that the isolate $\mathrm{FH}_{3-2}$ has a molecular weight of 164 $(\mathrm{M}+, 100)$ with $\mathrm{M}+1: 165$ (10.41) and $\mathrm{M}+2: 166(0.94)$ so that the isolates were thought to have the molecular structure $\mathrm{C}_{10} \mathrm{H}_{12} \mathrm{O}_{2}{ }^{17}$. From the molecular structure, $\mathrm{FH}_{3-2}$ isolate had a DBE value (double bond equivalent) of 5 so it was suspected to have a base frame consisting of one aromatic ring and one double bond. This basic framework was reinforced by fragments of $\mathrm{m} / \mathrm{z}$ ions 77 derived from $\mathrm{C}_{6} \mathrm{H}_{5}$ ions and $\mathrm{m} / \mathrm{z}$ 91 ion fragments derived from tropillary ions $\left(\mathrm{C}_{7} \mathrm{H}_{7}\right)$ and in the presence of an $\mathrm{m} / \mathrm{z} 55$ ion fragment derived from $\mathrm{C}_{4} \mathrm{H}_{7}$ ion fragments in the mass spectrum. The mass spectra of isolates had similarities with the mass spectrum of eugenol with a $97 \%$ equity index. To confirm the identity of $\mathrm{FH}_{3-2}$ isolates it is necessary to compare $\mathrm{FH}_{3-2}$ isolates with eugenol based on the literature.

Organoleptically isolate $\mathrm{FH}_{3-2}$ in the form of yellow liquor was almost colorless and smells the aromatic typical aroma of clove. This organoleptic had a resemblance to the organoleptic eugenol which was a colorless or slightly yellow liquid with the scent of cloves ${ }^{26}$. The ultraviolet spectrum of $\mathrm{FH}_{3-2}$ isolate showed some similarities to the eugenol ultraviolet spectrum. Comparison of ultraviolet spectra of isolates $\mathrm{FH}_{3-2}$ and eugenol based on literature can be seen in Table 7. From the data of ultraviolet spectrum comparison results, it could be seen that $\lambda$ max isolates $\mathrm{FH}_{3-2}$ and eugenol had similar values except for $\lambda$ maks $208 \mathrm{~nm}$ in isolates. The maximum wavelength at $208 \mathrm{~nm}$ was not included in the probability library because it was not a typical $\lambda$ max for the eugenol compound. The infrared spectra of $\mathrm{FH}_{3-2}$ isolate had absorption bands which were also owned by eugenol. Comparison of infrared spectra of isolates $\mathrm{FH}_{3-2}$ and eugenol based on literature can be seen in Table 8. Differences in the results of the infrared spectrum comparison appear from the relative shape and intensity of the bands. This difference might be due to differences in the measurement method and the infrared spectrophotometer used. Suspected identities of isolates $\mathrm{FH}_{3-2}$ were reinforced by the similarity of mass spectra of isolates $\mathrm{FH}_{3-2}$ with eugenol. Comparison of the fragmentation pattern of a mass spectrum of isolates $\mathrm{FH}_{3-2}$ and eugenol based on literature can be seen in Table-9. Previous studies have also shown that eugenol was one component of the sintok bark ${ }^{6,8}$. In addition, some literature also showed that eugenol was a common component of the genus Cinnamomum. ${ }^{25}$, ${ }^{26}$ From the mass spectrum, it was known that the isolate had a molecular weight of 222 $(\mathrm{M}+, 100)$ with $\mathrm{M}+1: 223$ (26.66) and $\mathrm{M}+2: 224$ (1.50) so that the isolates were thought to have the molecular structure of $\mathrm{C}_{15} \mathrm{H}_{26} \mathrm{O}{ }^{17}$. Of the molecular structure, $\mathrm{FH}_{3-3}$ isolate had a DBE value of 3 so it was thought to have a base frame consisting of one double bond and two cyclic structures. The presence of double bonds was amplified by the absorption band at $1515 \mathrm{~cm}^{-1}$ in the infrared spectrum and the presence of $\lambda \max$ at $206 \mathrm{~nm}$ indicating the presence of a double bond isolated. While the existence of two cyclic structures was supported by the absorption bands at $1062 \mathrm{~cm}^{-1}$ derived from the $\mathrm{CH}_{2}$ strain on the terpenoid cyclic system $271070 \mathrm{~cm}-1$ as well as the pattern of fragmentation of the isolated mass which was similar to the mass fragmentation of sesquiterpenoid compounds having two cyclic structures. ${ }^{31-33}$ The presence of 
RASĀYAN J. Chem.

Vol. 12 | No. 2 |898 - 906| April - June | 2019

cyclic structures was also supported by the fragment of m/z 55 (1,3-butadiene) suspected to arise as a result of a Diels-Alder retro reaction occurring on an unsaturated cyclic ring ${ }^{22}$. In addition, the results of the phytochemical screening of the n-hexane fraction also showed the presence of sesquiterpenoid compounds. Comparison of $\mathrm{FH}_{3-3}$ isolate mass fragmentation with some sesquiterpenoid compounds can be seen in Table-10. $\mathrm{FH}_{3-3}$ isolate mass spectrum had a similarity index of $85 \%$ with juniper camphor. Therefore, to ensure the identity of the isolates it was necessary to compare the isolates of $\mathrm{FH}_{3-3}$ with juniper camphor based on the literature.

Table-7: Comparison of Ultraviolet Isolate Spectra $\mathrm{FH}_{3-2}$ and Eugenol

\begin{tabular}{c|c|c}
\hline $\begin{array}{c}\text { Isolate } \mathrm{FH}_{3-2} \\
\lambda_{\text {maks }}, \mathrm{nm}\end{array}$ & $\begin{array}{c}\text { Eugenol } \\
\lambda_{\text {maks }}, \mathrm{nm}\end{array}$ & $\begin{array}{c}\text { Eugenol, NIST Spectra Database } \\
\lambda_{\text {maks }}, \mathrm{nm}\end{array}$ \\
\hline 208 & - & - \\
\hline 229 & 232 & 230 \\
\hline 275 & 282 & 278 \\
\hline
\end{tabular}

Table-8: Comparison of Infrared Spectra Isolates $\mathrm{FH}_{3-2}$ and Eugenol

\begin{tabular}{|c|c|c|c|c|c|c|}
\hline \multicolumn{3}{|c|}{ Isolate $\mathrm{FH}_{3-2}$} & \multicolumn{3}{|c|}{$\begin{array}{c}\text { Eugenol } \\
\text { (Spectra Database } \\
\text { for Organic Compound) }{ }^{18}\end{array}$} & \multirow[t]{2}{*}{ Presumption } \\
\hline $\begin{array}{c}\text { Wave } \\
\text { numbers } \\
\left(\mathrm{cm}^{-1}\right)\end{array}$ & $\begin{array}{l}\text { Bands } \\
\text { shape }\end{array}$ & Intensity & $\begin{array}{c}\text { Wave } \\
\text { numbers } \\
\left(\mathrm{cm}^{-1}\right) \\
\end{array}$ & $\begin{array}{l}\text { Bands } \\
\text { shape }\end{array}$ & Intensity & \\
\hline 3450 & wide & medium & 3618 & Wide & medium & $\mathrm{O}-\mathrm{H}$ \\
\hline 3087 & sharp & weak & 3077 & Sharp & weak & $\mathrm{C}-\mathrm{H}$ aromatic \\
\hline 3028 & sharp & weak & 3061 & Sharp & weak & $\mathrm{C}-\mathrm{H}$ aromatic \\
\hline 2925 & sharp & strong & 2939 & Sharp & weak & C-H aliphatic asymmetry \\
\hline 2857 & sharp & medium & 2843 & Sharp & weak & $\mathrm{C}-\mathrm{H}$ aliphatic asymmetry \\
\hline 1740 & sharp & medium & 1738 & Sharp & medium & $\mathrm{C}=\mathrm{C}$ aromatic \\
\hline 1594 & sharp & medium & 1514 & Sharp & strong & $\mathrm{C}=\mathrm{C}$ olefinic \\
\hline 1454 & sharp & medium & 1452 & Sharp & strong & C-H aliphatic \\
\hline 1128 & sharp & medium & 1122 & Sharp & strong & C-O alcohol tertiary \\
\hline
\end{tabular}

Table-9: Comparison of Fragmentation Pattern of Isolates $\mathrm{FH}_{3-2}$ and Eugenol

\begin{tabular}{c|c|c|c}
\hline \multicolumn{2}{c}{ Isolate $\mathrm{FH}_{3-2}$} & \multicolumn{2}{c}{$\begin{array}{c}\text { Eugenol } \\
\text { (WILEY Spectra Database) }\end{array}$} \\
\hline $\mathrm{m} / \mathrm{z}$ & relative intensity & $\mathrm{m} / \mathrm{z}$ & relative intensity \\
\hline 164 & 100 & 164 & 37 \\
\hline 149 & 37 & 149 & 32 \\
\hline 131 & 32 & 131 & 18 \\
\hline 121 & 19 & 121 & 39 \\
\hline 103 & 39 & 103 & 36 \\
\hline 91 & 36 & 91 & 50 \\
\hline 77 & 51 & 77 & \\
\hline
\end{tabular}

Table-10: Comparison of Mass Fragmentation Patterns Isolate FH3-3 with Some Sesquiterpenoid Compounds ${ }^{26-28}$.

\begin{tabular}{c|l|c|c|c|c|c|c|c|c|c|c|c|c} 
Compounds & \multicolumn{10}{c}{ Ion fragments (m/z) } \\
\hline S-selinen & & 204 & 189 & 175 & 161 & 147 & 133 & 119 & 105 & 91 & 81 & 67 & 55 \\
\hline Gorgonen & & 204 & 189 & 175 & 161 & 147 & 133 & 119 & 105 & 91 & 81 & 69 & 55 \\
\hline Sibiren & & 204 & 189 & 175 & 161 & 147 & 133 & 119 & 105 & 91 & 79 & 67 & 55 \\
\hline 5-epi-aristolocen & & 204 & 189 & 175 & 161 & 147 & 133 & 119 & 105 & 91 & 79 & 67 & 55 \\
\hline Isolate FH $_{3-3}$ & 222 & 204 & 189 & 175 & 161 & 147 & 133 & 121 & 105 & 93 & 81 & 67 & 55 \\
\hline
\end{tabular}

Organoleptically isolate $\mathrm{FH}_{3-3}$ in the form of a distinctive weak orange-yellow liquid. Juniper camphor itself was a compound belonging to the eudesmane sesquiterpene compound which was one of the essential oil components in some plant species such as Garcinia sp., Callicarpa sp. Protium sp. as well as on some CHEMICAL COMPOUNDS FROM THE SINTOK STEM BARK 903

Y. Iskandar and R. Mustarichie 
Araliaceae ${ }^{34-38}$. The alleged identity of isolates was reinforced by the similarity of the fragmentation pattern of FH3-3 isolate mass with juniper camphor. From the mass spectrum, it was known that FH3-3 isolate had a molecular weight of 222 (see Fig.-1) with $\mathrm{C} 15 \mathrm{H} 26 \mathrm{O}$ molecular structure. Isolate $\mathrm{FH} 3-3 \mathrm{had} \mathrm{a} \mathrm{m} / \mathrm{z}$ fragmentation pattern (relative intensity): 222 (1), 208 (17), 189 (20), 161 (16), 147 (13), 135 (21), 121 (15), 105 (26), 93 (35), 81 (51), 67 (43), 43 (100, base peak). The mass spectral pattern of FH3-3 was similar to that of the juniper camphor mass spectrum pattern with an $85 \%$ equality index. Moreover, the alleged identity of isolates was also supported by previous studies which showed that juniper camphor was one component of the sintok bark. ${ }^{6,8}$.

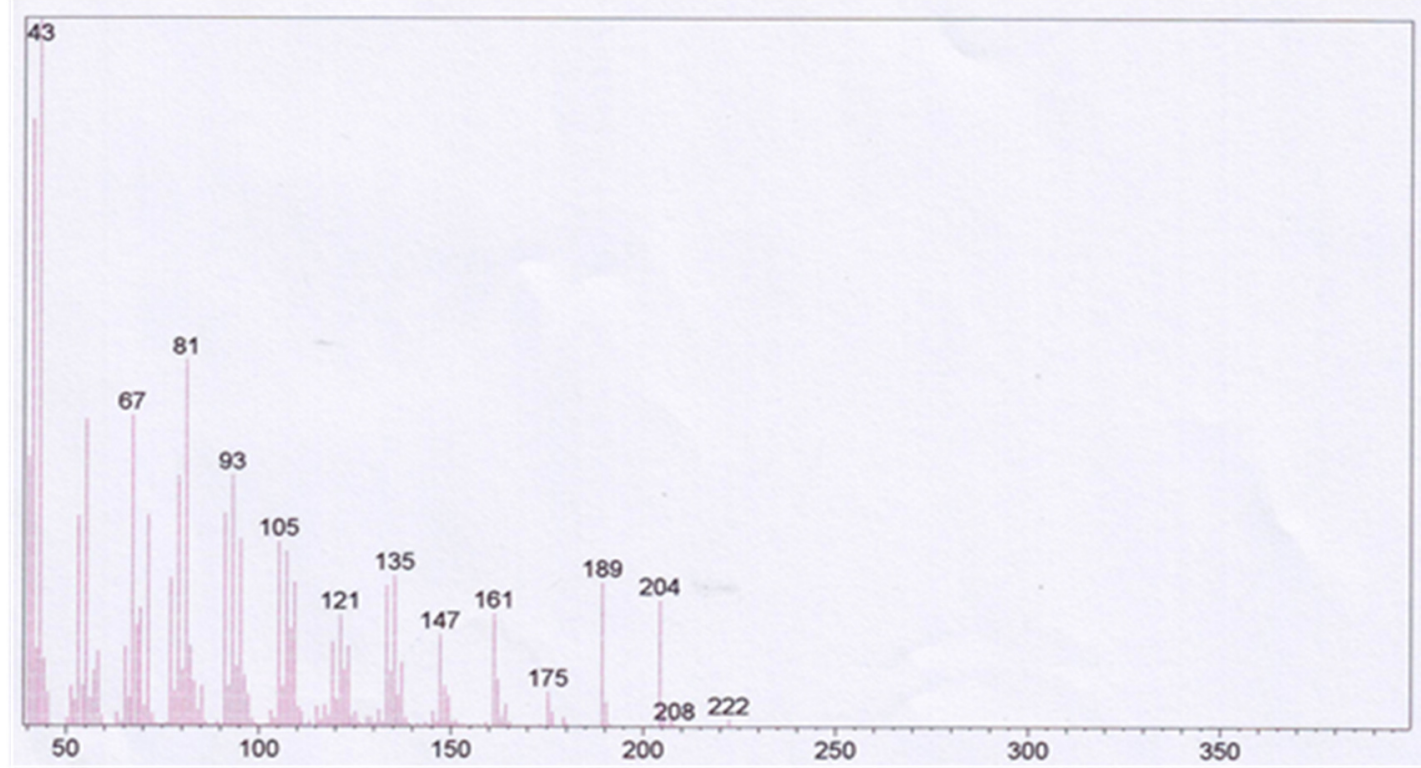

Fig.-1: Mass Spectrum of Isolate $\mathrm{FH}_{3-3}$

Determination of chemical compounds from plants that use methods similar to the methods listed here has been carried out by many people. Raji et.al, for example, reported secondary metabolites like alkaloids, flavonoids, tannins, and saponins were extracted from four medicinal plants viz. Cassia alata, Thespesia populnea, Euphorbia hirta, and Wrightia tinctoria and characterized by UV, TLC, FTIR and GCMS analysis ${ }^{39}$. Insanu et.al mentioned isolation non-alkaloid compounds in the Cinchona. officinalis bark using spectroscopic methods (UV, IR, ESI-MS, NMR (1H-, 13C-, HSQC, and HMBC) ${ }^{40}$.Study in vitro antioxidant activity of isolated compound from methanolic stem extracts of Jasminum auriculatum was studied by Srivastava et.al $l^{41}$.

\section{CONCLUSION}

Based on phytochemical screening results, it was found that the n-hexane fraction of sintok bark (Cinnamomum sintoc Bl.) contained tannin, polyphenol, monoterpenoid and sesquiterpenoid and triterpenoids. From this fraction, isolates $\mathrm{FH}_{3-2}$ and $\mathrm{FH}_{3-3}$ were obtained. $\mathrm{FH}_{3-2}$ isolate was obtained in the form of pale yellow liquid and typical aromatic odor similar to clove aroma while $\mathrm{FH}_{3-3}$ isolate was obtained in the form of a weak yellow odor orange. Based on the analysis of the ultraviolet spectrum, infrared spectrum, GC-MS spectra, as well as the results of the comparison of literature data, $\mathrm{FH}_{3-2}$ isolates were thought to be eugenol compounds while $\mathrm{FH}_{3-3}$ isolates were thought to be juniper camphor compounds.

\section{ACKNOWLEDGMENT}

We thank Muhammad Zulfikar Biruni for technical support.

\section{REFERENCES}

1. K. Heyne, 1987, Indonesia Useful Plants Volume II (Indonesian: TumbuhanBerguna Indonesia. Jilid II). Jakarta: Badan Penelitian dan Pengembangan Kehutanan, pp. 134. 
RASĀYAN J. Chem.

Vol. 12 | No. 2 |898 - 906| April - June | 2019

2. P. Ranasinghe, S. Pigera, G.A. Sirimal Premakumara, P. Galappaththy,G.R. Constantine and P. Katulanda. BMC Complement Altern Med., 13, 275(2013), DOI: 10.1186/1472-6882-13-275

3. P.V. Rao, and S.H. Gan. Evid Based Complement Alternat Med., 2014,642942, DOI: $10.1155 / 2014 / 642942$

4. H. Jian-feng, H. V. der Werff, L.Li, H.W. Li. Molecular Phylogenetics and Evolution 96(3), 33(2016), DOI: $10.1016 /$ j.ympev.2015.12.007

5. S. Pratiwi, T. Hertiani, E. Lagendijk, S. de Weert, International Journal of Pharmacy and Pharmaceutical Sciences, 7(4), 183(2015), DOI: 10.4172/2376-0354.1000119

6. BPOM, 2006, Standardization Quality Report of Simplicia of Cinnamomum sintoc Bl. stem Bark Extract (Indonesian: Laporan Standardisasi Mutu Ekstrak Simplisia Kulit Batang Sintok (Cinnamomum sintoc Bl.), Jakarta: Badan Pengawas Obat dan Makanan RI.

7. W. Phutdhawong, R. Kawaree, S. Sanjaiya, W. Sengpracha, and D. Buddhasukh, Molecules, 12, 868(2007), DOI: $10.3390 / 12040868$

8. C. Sunardi, S.A. Sumiwi, Y. Iskandar, S. Soeryati, D Gozali, 2005, Laboratory Testing Report for Quality and Security Practice of Indonesian Original Drug Extract Cinnamomum sintoc Bl.Bandung: Jurusan Farmasi, Fakultas Matematika dan Ilmu Pengetahuan Alam, Universitas Padjadjaran.

9. Dictionary of Natural Products. [CD-ROM Computer File]. Chapman and Hall/CRC Press, p.180200(2006)

10. N Saidi, H Helwati, LQ Lubis, M Bahi, Jurnal Natural, 17(2), 77(2017.)

11. S. Megantara, D. Utami, L. Puspitasari, R. Mustarichie, J. Pharm. Sci. \& Res., 9(9), 1478(2017).

12. R. Mustarichie S. Megantara, N. M. Saptarini, Asian J. Pharm. Clin. Res., 10(11), 331(2017), DOI: 10.22159/ajpcr.2017.v10i11.21118

13. R. Mustarichie, S. Warya, M. Moektiwardoyo, S. Megantara, F.A. Saputri, World Journal of Pharmacy and Pharmaceutical Sciences, 3(10), 72(2014).

14. R. Mustarichie, J. Levita, J. Arpina, Med. J. Indone.s, 23(1), 15(2014), DOI: 10.13181/mji.v23i1.684 R. Mustarichie, Z.Udin, A. Muhtadi, E. Surahman, A. Subarnas, and S. Supriyatna, Int. Res. J. Pharm. App Sci., 2(3), 56(2012).

15. R. Mustarichie, S. Warya, N.M. Saptarini, I. Musfiroh, J. App. Pharm. Sci., 6,109(2016), DOI: 10.7324/JAPS.2016.60916

16. R. Mustarichie, D. Runadi, D. Ramdhani. Asian J. Pharm. Clin. Res., 10, 1(2017), DOI: 10.22159/ajpcr.2016.v10i2.15724

17. N. R. Farnsworth. J. Pharm. Sci., 55, 225(1966)

18. S. Fatema, M. Farooqui, M. Ubale and P. M. Arif, Rasayan J. Chem., 12(2), 616(2019), DOI: 10.31788/RJC.2019.1222065

19. A. Godghate, R. Sawant and A. Sutar, Rasayan Journal of Chemistry, 5(4), 456(2012)

20. Departemen Kesehatan RI, 2008 Indonesian Herbal Pharmacopeia Indonesian: Farmakope Herbal Indonesia ) Edisi I. Jakarta: Departemen Kesehatan Republik Indonesia, pp. 162- 174, 180-182

21. U. Supratman, 2005, The structure elucidation of organic compounds (Indonesian: Elusidasi Struktur Senyawa Organik), Bandung: Jurusan Kimia FMIPA Universitas Padjadjaran.

22. L.D Field, S. Sternhell, J.R. Kalman, 2013. Organic Structures from Spectra, 5th Ed., Wiley.

23. K. Nakanishi, Science, 140(3567), 648 (1963), DOI: 10.1126/science.140.3567.648

24. R. M. Silverstein, C.G. Bassler, T.C. Marril, 1974, Spectrometric Identification of Organic Compounds, 3rd Ed.,Wiley International, USA.

25. J.V. Jackson, M.S. Moos and B. Windon, 1986, Clarke's Isolation and Identification of Drugs, London: HE Pharmaceutical Press.

26. NIST, Search for Species Data by Molecular Weight, 2017, Available from https://webbook.nist.gov/chemistry/mw-ser/

27. R. Sritharan, V. J. Jacob, S. Balasubramaniam, Journal of Herbs, Spices and Medicinal Plants, 2, 49 (1994), DOI: 10.1300/J044v02n02_07

28. W. M. N.H. Wan Salleh, F. Ahmad, K.H. Yen, R. M. Zulkifli, Pharmaceutical Sciences, 22, 60(2016). 29. R. S. Bulan, S. Soedigdo, A. Buchari. Lantaden XR, Journal Matematika dan Sains, 9, 209(2004). 
RASĀYAN J. Chem.

Vol. 12 | No. 2 |898 - 906| April - June | 2019

30. D. H. Hochmuth. Retention Index Guide of Mass Spectrometry, 2004, Available from http://www.massfinder.com, hochmuth@web.de.

31. L. Hu, L. Ji-Kai. Z., Naturforsch., 57c, 571(2002), DOI: 10.1515/znc-2002-7-803

32. C. L. Stele, J. Crook, J. Bohlmann, R. Croteau, The Journal of Biological Chemistry, 273, 2078(1998).

33. J.S. Roberts, 1972, Chemistry of Terpenes and Terpenoids. London: Academic Press, pp.146.

34. L.S. Chagonda, J.C. Chalchat, J. Flavour Fragr., 20, 313(2005), DOI: 10.1002/ffj.1420

35. M. Kobaisy, M. R. Tellez,F.E. Dayan, S.O. Duke, Phytochemistry, 61, 37(2002).

36. A.C. Siani, I.S. Garrido, S. S. Monteiro, E.S. Carvalho, M.F.S. Ramos. Biochem. Syst. Ecol., 32,477(2004), DOI: 10.1016/j.bse.2003.11.003.

37. R.J. Weston, Z. Naturforsch. 59c, 35(2004).

38. P. Raji, B. Rohan, A. Samrot, P.D. Kumar, Rasayan Journal of Chemistry, 1, 123(2019), DOI: 10.31788/RJC.2019.1214054

39. M. Insanu, S. Aziz, I. Fidrianny, R. Hartati, E. Sukrasno, and K.R. Wirasutisna, Rasayan J. Chem., 12, 519(2019), DOI:10.31788/RJC.2019.1221831

40. J. Srivastava, D. Deepak and P. Prakash, Rasayan J. Chem., 8, 161(2015)

[RJC-5188/2019] 